\title{
The hierarchy of needs to inclusive design
}

\author{
Júlio Carlos de Souza van der Linden ${ }^{\mathrm{a},{ }^{*}}$ and Clariana Fischer Brendler ${ }^{\mathrm{b}}$ \\ ${ }^{a}$ Departamento de Design e Expressão Gráfica, Universidade Federal do Rio Grande do Sul, Av. Osvaldo \\ Aranha, 99/408, Porto Alegre, RS, Brasil \\ ${ }^{\mathrm{b}}$ Programa de Pós-graduação em Design, Universidade Federal do Rio Grande do Sul, Av. Osvaldo Aranha, \\ 99/607, Porto Alegre, RS, Brasil
}

\begin{abstract}
This paper focuses Design importance in the development of effectively inclusive products basead on Design Emotional approach, allowing children with disabilities to experience playing in the childhold as an instrument for social integration. The methodology used to develop this study was based on literature review, considering the following themes: emotional design, accessibility and inclusion, emotion and development of children. As a result, we propose a new level of need to model the hierarchy of needs, of Jordan ("usability", "functionality" and "pleasure"), level with the inclusion of "dignity."
\end{abstract}

Keywords: accessibility; emotion; inclusion; PSN

\section{Introduction}

Artifacts have important role in the development of the child, either with special needs or not. The childhood is the period in which it carries out most of the emotional learning, key success factor for intellectual development. This paper discusses contributions of design to include children from different social and psychological conditions. So, it adopts the concept of emotional design as a basis for an effectively inclusive product design: "object-centered design and its objective aspects has lead to a humancentered design and their way of seeing, interpreting and living with the environment" '[1].

The issue of exclusion is not limited to accessibility. The feeling of being stigmatized also derives from the symbolic aspects, which may be aggravated by poor quality of the formal design of equipment and devices for use by People with Special Needs (PSN). The symbolic dimension of exclusion is a psychosocial stressor, and its consequences depend on the emotional maturity of each individual. Among other consequences left by the lack of emotional learning, rejection and depression may be the most damaging [2]. A child with a disability must participate without restrictions in the social environment. Therefore, it is necessary to consider the factors that affect their overall development.

\section{Method}

This work was developed based on literature review, considering the following themes: emotional design, accessibility and inclusion, emotion and child development.

\section{Results}

\subsection{Products and design}

Different visions concerning industrial products had been developed throughout the not-defined field of new products development. Engineers have some definitions generally based on the Theory of Technical Systems, managers have a approach centred on benefits to the costumers, and designers follow philosophers, anthropologists, sociologists and others human-centered thinkers to delimit their object of action.

According to the Theory of Technical Systems (TTS), a product essentially performs technical functions, despite others. TTS recognizes others

\footnotetext{
* Corresponding author. E-mail: editorial@iospress.nl. Check if the checkbox in menu Tools/Options/Compatibility/Lay out footnotes like Word 6.x/95/97 is selected if you make a footnote for the corresponding author.
} 
functions, but its approach emphasizes on technical functions, considering product primarily as the result of a process of transforming materials and energy [3]. A broader view is offered by Roozemburg \& Eeckels [4] "products are artifacts designed, produced, marketed and used by people because of their properties and functions that can play."

Design theorists, under the influence of communication sciences, see the product from its interaction with the user / consumer. A product can be defined as an interface between three domains: the user or a social worker who wants to carry out effective action, the task that the user wants to accomplish, and a tool or artifact, the user needs to perform an action. The interface tool reveals the character of objects and communicative content of information: the interface turns objects into products, the interface converts signals into interpretable information [5].

This view finds its equivalent in the concept of Man-Machine System, adopted in Ergonomics. The definition of man-machine system includes any type of physical object, apparatus, equipment, working environment, used to achieve a purpose [6]. The man's role in this system occurs in an active manner, by interacting with the machine to perform the function for which the system was designed. To Grandjean [7], the man-machine system represents the interplay between machines and humans. It constitutes a closed loop system where the information perceived and interpreted by man generates a control message that changes a work in progress. Based on this model are available to ergonomists and designers, ergonomic evaluation methods for products.

\subsection{Design and emotion}

Currently, design and emotion are considered related issues. But it is necessary to recognize that this is a new vision. For some years the dominant discourse followed the functionalist paradigm, who defines design activities and design products as objectives, thus not related with subjectives aspects.

One of the firsts authors on design and emotions themes, Patrick Jordan proposed a model, named The Hierarchy of Customer Needs [8]. This model considers the interaction between the consumer and the product on three levels: Functionality, Usability and Pleausre. Functionality is a prerequisite, but not good enough, when people have products that work, they want products that are easy to use. Finally, it is in- evitable that people want products that deliver emotional benefits, reaching the level of pleasure.

Another approach was developed by Desmet and Hekkert [9]. These authors consider emotions as the most important affective responses to the experience with products. They point that other affective responses, unlike emotions, are not directly related to the experience offered by a product. Their model, named Model of Product Emotions, considers three major possibilities of interaction between people and products: as event, as agent and as object. Each type may be experienced in different ways (e.g. a shoe could be perceived as an object for a girl who loves shoes, or as an agent for another girl who needs a shoe because she desires to meet someone at a party).

Also a pioneer in the field of design and emotion, Norman [10] deals with the emotions and products experience from the three levels of the brain: the visceral level, the behavioral and reflective level. Something is perceived as "beautiful" or "ugly" in a visceral level. At the behavioral level, the appearance does not count, but the performance. The overall impact of a product is produced in the reflective level [10].

\subsection{Design accessibility and inclusion}

The topics "accessibility" and "inclusion" are central issues for quality of life and full citizenship for people with special needs. This issue has been discussed at different levels of government, promoting the viability of the exercise by PSN rights to education, health and work [11]. Brazilian law gives the government the responsibility to serve people with disabilities as a priority by ensuring the accessibility (Law No. 7853/89), defined as

"The condition of possibility and scope for use with security and autonomy, space, furniture and urban equipment, the buildings, transport and postal systems and media to a person with disabilities or reduced mobility." (Law n . 10.098/2000)

The success of people in different areas - relationships, work and health - depends on emotional skills to be developed throughout life [2]. The human brain is malleable, new neural connections can be made and remade other, but childhood is that the basic brain architecture is formed: "habits acquired in childhood become fixed in the synaptic wiring of basic neural architecture and are more difficult to change later in life" [2]. 


\subsection{PSN 's cognitive and linguistic development}

Social environment is indispensable for cognitive and linguistic development, since the act of speech is a personal creation, and the culmination of language, as the expression with marked emphasis on the motor [12]. With this, two factors will influence the quality and speed of child's cognitive development in a: child's ability to interact with the environment and the environment's nature. Thus, the child would have the chance to experience the constructions of the sensorimotor period, which would lead to enrichment of the language.

Piaget [13] argues that the action is the source of an intelligent act, and the basic sensorimotor experiences for normal cognitive development. Based on this, one can see that children develop with physical disabilities have a cognitive deficit caused by the inability to move around the environment and object manipulation. Children with special needs manifest cognitive impairment due to constraints in sensorimotor experiences. Finnie [14] points out that language experiences are smaller due to the failure to exploit children's motricity.

Vygotsky [15] states that the laws that underlie cognitive development are the same for normal children and children with disabilities. The differences were the paths chosen by these children to process the world and adds that the functions of cognitive development appear first at the social level to then appear in the psychological as well. Vygotsky conceives the social and the individual as a unique system of interaction. The relationship established between the children with special needs people with good motor skills can be a key element in its development. The shared action would stimulate children's ability to establish social ties and foster cognitive performance.

Braga [16] states that disability is not in itself the driving force of the new ways that the child tends to seek PNE. The difficulties arising from this problem and its social consequences lead to new ways of looking.

Every child builds and guides the process of cognitive development through motivation, attention and action. A child with special needs has no limitations related to motivation and attention. The blockade is restricted to action.

Basing on this concept, the child acts in a PNE cognitive emphasis, from their motivations, as proposed by Vygotsky [15], and guides its development based on attention, motivation and internal action, as Piaget postulates [13].

\subsection{Psychological aspects applied to children with special needs}

According Trugillo (2006) much of the psychology of disabilities is closely linked to social psychology, ie, the interaction of that individual with others and the environment of each. Thus, an individual with special needs will be less limited by his disability, the attitude of society towards disability. The influence of society to exclude the different can be observed in the behavior of young children who seem don't have been influenced by society's standards, because they play freely with the different children. It is the attitude of society, in most cases, that will define disability as an impairment. The disabled individual will suffer the consequences of such a definition.

With regard to personality, there is no a type that defines individuals with disabilities. The only point in common among the disabled is their own limitation, ie, all have a deficit that discriminate against the "normal" population. Each individual is an integrated and functional whole, thus should be understood in his/her personality structure. This consists of inherited traits and acquired: thus the personality of an individual can only be understood by all of its different aspects: bio-psycho-social. The disability will be experienced in different ways according to the personality structure of each. So some see disability as a challenge to be overcome with new ways to adapt and look for other references. Others show negative reactions to the situation of accommodation with moments of depression and anxiety.

Generally speaking disability means: action and personal growth limits. Consequently the individual is segregated from society, away from normal opportunities for achievement (personal, professional, social, emotional, etc.). Specifically for children with cerebral palsy, they have a deficiency in the consciousness of his own body because of the difficulty in relation to its members and its center of gravity which generally is subject to fluctuations. This can lead to a distortion of real sense of place, a difficulty in adapting to the world in their relations of space, time and interpersonal relationships. The fear of falling, the pain when speaking, dissatisfaction for failing to perform tasks brings moments of insecurity and anxiety for these children. There are numerous limitations that disturb and hinder the harmonious 
development of personality of children with disabilities.

The situation of deficiency favors the appearance of frequent states of depression, dissatisfaction, insecurity, reactions of aggression, impulsivity, low frustration tolerance. Frustration can lead to behaviors such as aggression, mistrust, anxiety, regressive behaviors, impatience, depression, jealousy, blocks, escape, difficulty in social adaptation. It is essential to encourage individuals to take you progressively achieve improvements to children is of great value to clarify them about the consequences of their disabilities, helping them to live with it and overcome its limitations. The most important thing is to keep the level of expectation, individuals with disabilities within the reality and make them more socially adapted [17].

\subsection{Inclusion and leisure in childhood}

Human development is the sum of the growth process (biological) with the incorporation of children in civilization (cultural). These two elements are essential for the proper development of the child, the biological and cultural.

In the case of a child with a biological impairment (vision within a traditional perspective of organic or psychological malfunction of the disabled person) is common to see an incomplete cultural development. This means that in this case human development occurs in an unequal manner, suffer when a child has a disability, which creates a different outcome in their cultural development.

The activity of play is something of great importance in the lives of children. They begin to play before even talking or walking [18]. Because of this, creating artifacts that allow situations in which children are together in their differences is to propose that any child would have, in the use of these, an important element in its development. It would enable to integrate situations where any child could have a biological and cultural development equal to that of all children.

Leisure in childhood deserves special care because the child has too much free time and because childhood is the stage where it acquires motor skills, as well as the formation of habits of social life. The search for happiness and fulfillment are major motivating forces achieved through leisure. Child's life, from this perspective, is a series of activities that are usually related to social integration. According Gaelzer [19] routine and monotony are the main causes of sadness and boredom. The renewed joy through social integration is rich in fantasy, provides an environment of invention and creativity that are important for cognitive development.

Medeiros [20] reports on the need for social integration in children's lives, and in with disabilities is even greater. Not only in regard to their motor rehabilitation, as well as the cognitive aspect, linguistic, and psychosocial. Activities at different times and situations, such as recreation and interaction with appropriate artifacts, in which she will be more interested and predisposed to exercise and handling, should be encouraged.

\section{Discussion}

The inclusion of people into society begins in early childhood through the interactions with the environment. Whereas in the contemporary world the artificial became the natural environment of humans, the design has an important role. Persons who need special facilities for living, they become excluded when the symbolic processes generate stigma.

Norman (2004) presents links between affect and usability, there are certainly also between emotions and accessibility. Reframing the Hierarchy of Customer Needs (Jordan, 2000) may suggest that the PSN for the interaction between the consumer and the product is given in levels: functionality, accessibility and pleasure. Therefore, emotional design can positively influence the development of products that promote inclusion.

Considering the needs of consumption, PSN differ from others only on their need for recognition as worthy of dignity. Therefore, beyond the levels already suggested by Jordan (functionality, usability and pleasure), should be explicitly included the level of dignity, as opposed to the stigma that arises from the differentiation in this some assistive technology solutions not consider the emotional dimension. Based on these considerations, the Hierarchy of Needs to Inclusive Design is proposed as presented in Figure 1

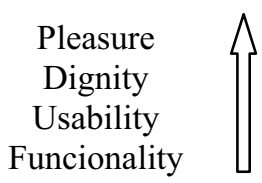

Figure 1. Hierarchy of Needs to Inclusive Design 


\section{Conclusion}

The lack of attention to symbolic aspects of the artifacts for children with special needs, often aggravated by poor formal project contributes to the strengthening of the stigma associated with People with Special Needs (PSN). The cultural and biological development of children PSN can be enhanced by offering products that allow the inclusion in early childhood.

The reformulation of the model hierarchy of needs, proposed by Jordan (2000), with the inclusion of a new level of need, the dignity, aims to help reduce the sense of stigma that emerges differentiation generated by products intended only for PSN

\section{References}

[1] Mont Alvão, Cláudia e Damazio, Vera, 2008. Design, ergonomia, emoção. Rio de Janeiro: Mauad.

[2] Goleman, Daniel, 2007. Inteligência emocional: por que ela pode ser mais importante que o QI. Rio de Janeiro: Objetiva.

[3] Hubka, Vladimir, Eder, W. Ernst., 1988. Theory of Technical Systems: A Total Concept Theory for Engineering Design. Berlin: Springer-Verlag.

[4] Roozemburg, N.F.M., Eekels, J. , 1995. Product Design Fundamentals and Methods. Chichester: John Wiley \& Sons.

[5] Bonsiepe, G. , 1997. Design: do material ao digital. Florianópolis: FIESC/IEL.

[6] McCormick, Ernest J., 1980. Ergonomia: Factores humanos en Ingenieria e Diseño. Barcelona: Gustavo Gili.

[7] Grandjean, E., 1998. Manual de Ergonomia - Adaptando o Trabalho ao Homem. Bookman: Porto Alegre.

[8] Jordan, Patrick W., 2000. Designing Pleasurable Products: an introduction to the new human factors. London: Taylor and Francis.

[9] Desmet, P.M.A.; Hekkert, P.P.M. The basis of Product Emotion. In: GREEN, William S.; JORDAN, Patrick W. , 2002. Pleasure with Products: beyond usability. London: Taylor \& Francis, p.61-68.

[10] Norman, Donald, 2004. Emotional Design. New York: Basic Books.

[11] Lima, Luiz Henrique. Acessibilidade para pessoas portadoras de deficiências: requisito da legalidade, legitimidade e economicidade das edificações públicas. Disponível em: $<$ http://jus2.uol.com.br/doutrina/texto.asp?id=9167>. Acessado em: 29 abril. 2011.

[12] Lacerda, E.T.L., 1993. Reflexões sobre a terapia fonoaudiológica da criança paralítico- cerebral. São Paulo: Memnon.

[13] Piaget, J.,1980. A linguagem e o pensamento da criança. Rio de Janeiro: Fundo de Cultura.

[14] Finnie, N. A., 1979. O manuseio em casa da criança com paralisia cerebral. São Paulo: Manole.
[15] Vygotsky, L.S., 1964. Pensamiento y lenguaje. Buenos Aires: Lautaro.

[16] Braga, L.W., 1995. Cognição e paralisia cerebral: Piaget e Vgotsky em questão. Salvador: Sarah letras.

[17] Trugillo, Renata do Carmo de Assis. Psicóloga, trabalha com reabilitação de crianças e adultos com deficiência física no Lar Escola São Francisco. Disponível em: www.revistapsicologia.com.br/materias/pontoDeVista/m_po ntodevista_paralisiacerebral.htm. Acessado em 16/05/ 2006.

[18] Rodulgo, Ricardo, 1990. O Brincar e o Significante. Porto Alegre: Artes Médicas.

[19] Gaelzer, Lenea, 1979. Lazer: Bênção ou maldição? Rio Grande do Sul: Sulina.

[20] Medeiros, Ethel Bauzer, 1975. O lazer no planejamento urbano. Rio de Janeiro: Fundação Getúlio Vargas. 